\title{
Порушення якості життя опікунів постінсультних пацієнтів $з$ афазією
}

\author{
УДК 616.89-008.434.5:616.831-005.1:[330.59+314] \\ Я. В. Сибірякін, М. С. Балаж
}

Національний університет фізичного виховання і спорту України, Київ, Україна

\begin{abstract}
Резюме. Мета. Дослідити вплив захворювання на якість життя неофіційних опікунів постінсультних пацієнтів із сенсомоторною афазією. Методи. Аналіз даних опитування, статистична обробка результатів. Результати. Якість життя опікунів знижується за різними доменами нерівномірно. Найбільш суттєве зниження показників якості життя спостерігали в доменах «фізичне здоров'я» та «психічне здоров'я». Меншою мірою було виявлено порушення у домені «оточуюче середовище», майже не було погіршення у домені «соціальні відносини». Не спостерігали статистично значущої різниці між показниками якості життя опікунів різної статі. Виявили тенденцію до більш тяжких наслідків захворювання для членів подружжя порівняно з дітьми та сиблінгами пацієнтів. Сенсомоторна афазія є значним обтяжуючим фактором після перенесеного інсульту. Вона негативно впливає на різні аспекти якості життя родичів тематичних хворих, які доглядають за пацієнтами. В гострому періоді захворювання найбільше навантаження спостерігається на психічне та фізичне здоров'я опікунів.

Ключові слова: інсульт, афазія, опікуни, якість життя.
\end{abstract}

\section{Impaired quality of life of caregivers of post-stroke patients with aphasia}

Ya. V. Sybiryakin, M. S. Balazh

National University of Physical Education and Sport of Ukraine, Kyiv, Ukraine

Abstract. Objective. To investigate the impact of the disease on the quality of life of unofficial caregivers of post-stroke patients with sensorimotor aphasia. Methods. Survey data analysis, statistical processing of results. Results. Caregivers' quality of life is declining unevenly across different domains. The most significant decline in quality of life was observed in the domains «physical health» and «mental health». To a lesser extent, there were violations in the domain of «environment», there was almost no deterioration in the domain of «social relations». There was no statistically significant difference between the quality of life of caregivers of different sexes. There was a tendency for more severe consequences of the disease for spouses, compared with children and sibling patients. Sensorimotor aphasia is a significant aggravating factor after a stroke. It negatively affects various aspects of the quality of life of relatives of thematic patients who care for patients. In the acute period of the disease, the greatest burden is observed on the mental and physical health of caregivers.

Keywords: stroke, aphasia, caregivers, quality of life. 
Постановка проблеми. Наслідки серцевосудинних розладів $є$ однією з основних причин інвалідності та смертності населення у світі. За даними Всесвітньої організації охорони здоров'я (ВОО3), кожен рік через серцево-судинні захворювання помирає близько 17,9 млн людей. Більше ніж 6 млн смертей пов'язані безпосередньо з інсультом [16]. В Україні щороку трапляється близько 150 тис. інсультів і понад 100 тис. людей помирають від інсульту та інших порушень кровотоку в мозку [4]. Інсульт також $€$ однією 3 основних витрат на охорону здоров'я та другою причиною інвалідності населення України [2, 15]. Від 15 до 30 \% людей, які пережили інсульт, залишаються зі стійкими фрункціональними порушеннями, і лише 13 \% повертаються до роботи $[6,11]$.

Згідно з визначенням ВООЗ, інсульт - клінічні ознаки вогнищевих (часом глобальних) порушень мозкової фрункції, що швидко розвиваються та тривають більше 24 год або призводять до смерті без явної причини, крім судинної [10]. Клінічна картина може істотно відрізнятися залежно від місця та розміру морфологічних змін, що були отримані під час інсульту. Крім типових рухових розладів, також можуть спостерігатися порушення чутливості, розлади мови, психічні розлади тощо [3].

Одним з найбільш важких наслідків мозкових уражень $€$ афразія. Сенсомоторна афразія (також відома як тотальна та глобальна) - супутнє захворювання, яке виникає внаслідок інсульту та впливає на здатність обробляти мовленнєву інфрормацію, що надходить ззовні, і відтворювати мовлення, порушує здатність спілкуватися усно, за допомогою знаків чи письмово [8].

Порушення здатності до спілкування у постінсультних пацієнтів здійснює значний психоемоційний вплив на їхніх родичів та тих, хто доглядає за ними. Вони переживають більший стрес порівняно $з$ доглядальниками пацієнтів без афразії, мають симптоми депресії, самотності та більше сімейних труднощів, емоційних і фрінансових проблем [5].

S. Ross, R. G. Morris - одні 3 перших дослідників, які вивчали навантаження на опікунів пацієнтів із постінсультною афазією. У 1988 р. у своєму дослідженні вони оцінили 20 подружніх пар, в яких один із членів подружжя мав постінсультну афазію. Автори дійшли висновку про значний рівень напруження в сім'ї, який можна порівняти з напруженням у родинах людей із деменцією [12].

Ці дані були підтверджені та доповнені через кілька років В. М. Draper et al., які обстежили опікунів літніх людей з інсультом, деменцією та хворобою Паркінсона. Отримані результати показали, що опікуни відчувають подібне за типом та рівнем психосоціальне навантаження, незалежно від захворювання [7].

У дослідженні P. Servaes et al. було показано, що опікуни відчували постійний стрес та роздратування через неможливість звичного спілкування з людиною, що має афразію. Також суттєвим фактором погіршення якості життя була зміна ролей у сім'ї, яка сприяла втраті сексуальних відносин та зниженню задоволеності подружнім життям [13].

T. Bakas et al. у своєму дослідженні за участю 159 сімей порівняли навантаження, яке відчувають люди, що доглядають за постінсультними хворими з афазією та без неї. Результати показали, що проблеми спілкування між пацієнтом 3 афразією та опікуном були асоційовані з більшою складністю виконання завдань, депресивними симптомами, розладами фрізичного здоров'я, фрінансовими проблемами, нестачею часу на соціальну діяльність тощо [5].

У нещодавньому дослідженні P. Y. Gunawan, K. A. Iswara також було підтверджено дані про підвищення частоти та тяжкості депресії серед опікунів пацієнтів з афразією порівняно з опікунами пацієнтів без неї [9].

Аналіз наявних досліджень показав, що більшість із них основну увагу приділяє оцінюванню психоемоційного стану опікунів, а не якості життя. Також слід враховувати, що проаналізовані дослідження мають недоліки: зокрема, у пацієнтів була різна тяжкість афразії, більшість опікунів, включених до досліджень, були жінками тощо. Це все могло призвести до викривлення кінцевого результату та хибних висновків, на що вказують самі автори публікацій. Враховуючи вищевказане, проблема дослідження якості життя опікунів осіб із постінсультною афразією залишається актуальною та потребує подальшого вивчення.

Роботу виконано відповідно до плану науково-дослідної роботи (НДР) Національного університету фрізичного виховання і спорту України (НУФВСУ) на 2016-2020 рр. за темою 4.2 «Організаційні та теоретико-методичні основи фрізичної реабілітації осіб різних нозологічних, профресійних та вікових груп» (номер держреєстрації 0116U001609) та відповідно до плану НДР НУФВСУ на 2021-2025 рр. за темою 4.2 «Відновлення фрункціональних можливостей, діяльності та участі осіб різних нозологічних, професійних та вікових груп засобами фрізичної терапії» (номер держреєстрації 0121U107926). 
Мета дослідження - дослідити вплив захворювання на якість життя неофіційних опікунів постінсультних пацієнтів із сенсомоторною афразією.

Методи дослідження: аналіз даних опитування, статистична обробка результатів.

Дослідження проводили на базі Комунального некомерційного підприємства «Олександрівська клінічна лікарня міста Києва». У ньому взяли участь 62 опікуни пацієнтів із порушенням мови у вигляді сенсомоторної афразії внаслідок перенесеного інсульту.

У дослідження були включені тільки опікуни пацієнтів із тотальною сенсомоторною афразією (пацієнти повністю не розуміли звернену до них мову та не могли говорити). Опікунами були близькі родичі постінсультних пацієнтів: діти (донька/син) - 34 особи, подружжя (чоловік/ дружина) - 20 осіб, сиблінги (брат/сестра) 8 осіб. У дослідженні брав участь той член родини, який проводив найбільшу частину часу 3 пацієнтом та доглядав за ним. Вік опікунів - від 35 до 80 років (середній вік ( $\bar{x} \pm \mathrm{S}): 54,1 \pm 11,3$ року). 32 особи з опитаних опікунів були чоловіки та 30 - жінки.

Опитування опікунів проводили через 13 тиж. після перенесеного інсульту.

Усі особи, які брали участь у дослідженні, підписали інформовану фрорму згоди. Дослідження було проведено 3 дотриманням міжнародних принципів Гельсінкської декларації Світової медичної асоціації [17] та відповідно до Закону України «Основи українського законодавства про охорону здоров'я» про етичні норми і правила проведення медичних досліджень за участю людини [1].

Оцінювання якості життя опікунів здійснювали за допомогою короткого опитувальника BOO3 «The World Health Organization Quality of

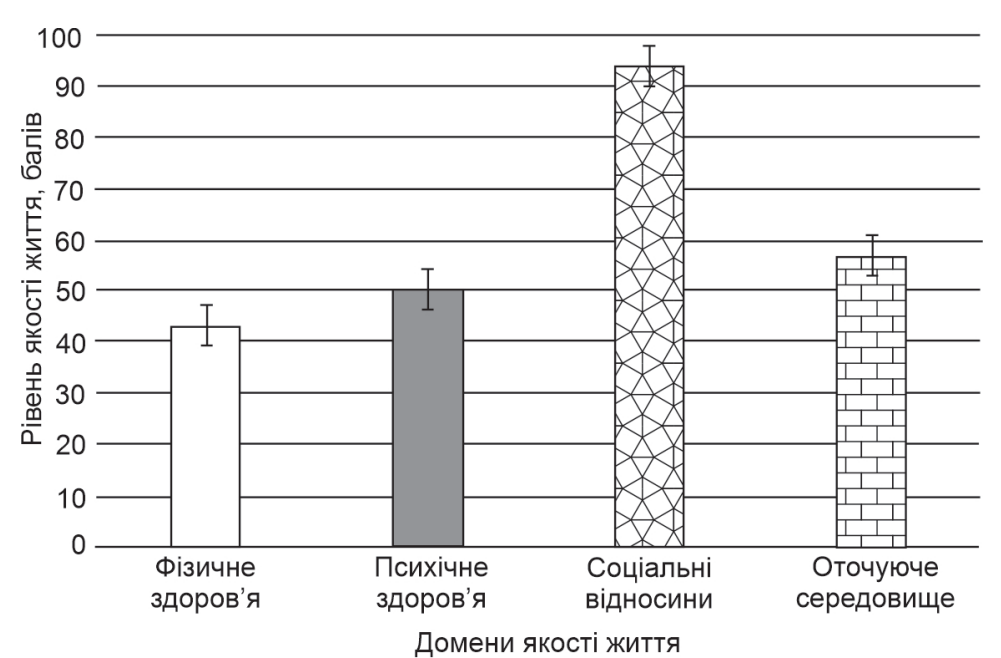

Life» (WHOQOL-BREF) [13]. WHOQOL-BREF анкета для самостійного застосування, яка містить 26 запитань щодо уявлення особистості про своє здоров'я та самопочуття протягом останніх двох тижнів. Відповіді на запитання даються за шкалою Лікерта від 1 до 5. Опитувальник оцінює чотири домени: фрізичне здоров'я, психічне здоров'я, соціальні відносини та оточуюче середовище. Кожен із доменів оцінює різні аспекти якості життя: «фрізичне здоров'я» - діяльність у повсякденному житті, залежність від лікарських речовин та медичних засобів, енергійність та втома, мобільність, біль і дискоморорт, сон і відпочинок, працездатність; «психічне здоров'я» прийняття свого зовнішнього вигляду, негативні та позитивні почуття, самооцінка, мислення, навчання, пам'ять і концентрація; «соціальні відносини» - особисті стосунки, соціальна підтримка, статева активність; «оточуюче середовище» фрінансові ресурси, свобода та безпека, охорона здоров'я і соціальна допомога (доступність та якість), домашнє середовище, можливості для отримання нової інорормації, участь та можливості для відпочинку і дозвілля, транспорт. Оцінювання здійснювали за 100-бальною шкалою: вищий бал відповідав вищому рівню якості життя.

Методи статистичної обробки даних. Аналіз відповідності виду розподілення кількісних показників закону нормального розподілення перевіряли за критерієм Шапіро-Уілка (W). Для кількісних показників, які мали нормальне розподілення, визначали середнє значення $(\bar{x})$ та середньоквадратичне відхилення (S). Значущість різниці оцінювали за допомогою t-критерію Стьюдента. Статистично значущими вважали відмінності при $p<0,05$. Статистичний аналіз отриманих результатів проводили за допомогою програми Statistic 7.0 (StatSoft, США).

Результати дослідження. У ході дослідження було отримано дані, які свідчать про погіршення якості життя опікунів постінсультних пацієнтів із сенсомоторною афазією.

Проведене анкетування (62 неофіційних опікуни) виявило, що якість життя опікунів знижується за різними доменами нерівномірно. Більше за все порушується фрізичне $(43,15 \pm$ 9,3 бала) та психічне $(50,5 \pm$ 9,3 бала) здоров'я. Дещо меншою мірою було виявлено порушення у домені «оточуюче середовище» (56,9 \pm 11,2 бала) та майже

Рисунок 1 - Якість життя опікунів (n = 62) постінсультних пацієнтів із сенсомоторною афазією (за даними оцінювання за допомогою опитувальника WHOQOL-BREF) 


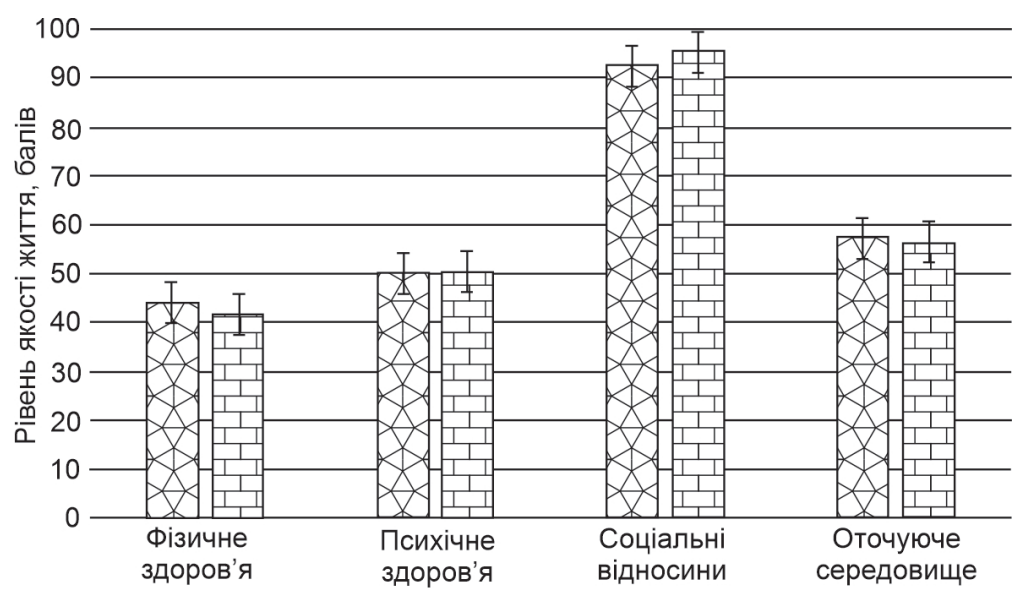

Домени якості життя

Чоловіки $(n=32)$

не було помітного погіршення у домені «соціальні відносини» $(94,1 \pm 8,4$ бала).

Показники якості життя опікунів постінсультних пацієнтів із сенсомоторною афразією за даними опитування за допомогою WHOQOL-BREF представлено на рисунку 1.

При порівнянні отриманих даних для опікунів різної статі не було виявлено статистично значущої різниці між показниками якості життя в жінок та чоловіків. Так, показник фрізичного здоров'я становив 41,9 \pm 7,1 бала для жінок та 44,3 \pm 10,9 бала для чоловіків ( $>0,05)$; показник психічного здоров'я $-50,7 \pm 8,4$ бала для жінок та $50,3 \pm 10,5$ бала для чоловіків ( $>>0,05)$; показник соціальних відносин - 95,5 \pm 7,5 бала для жінок та 92,8 \pm 9,2 бала для чоловіків ( $>>0,05)$; показник оточуючого середовища $56,3 \pm 11,8$ бала для жінок та 57,5 \pm 10,7 бала для чоловіків ( $p>0,05)$.

Показники якості життя опікунів постінсультних пацієнтів із сенсомоторною афазією залежно від статі опікунів представлено на рисунку 2.

Було проаналізовано показники якості життя опікунів пацієнтів залежно від ступеня споріднення 3 пацієнтом (табл. 1). Опікунів було розподілено на три групи: група 1, до якої належали діти пацієнтів ( $\mathrm{n}=34)$, група 2 - подружжя паці-
Рисунок 2 - Якість життя опікунів постінсультних пацієнтів із сенсомоторною афазією залежно від статі опікунів (за даними оцінювання за допомогою опитувальника WHOQOL-BREF)

єнтів (n = 20), група 3 - сиблінги пацієнтів $(n=8)$.

Порівняльний аналіз даних показав, що середні значення показників якості життя за всіма доменами були найнижчими в групі 2, тобто серед подружжя пацієнтів із сенсомоторною афразією: показник якості життя за доменом «фрізичне здоров'я» становив 40,3 \pm 7,1 бала, за доменом «психічне здоров'я» $-48,7 \pm 8,6$ бала, «соціальні відносини» - 92,9 \pm 8,8 бала, «оточуюче середовище» - 54,4 \pm $\pm 12,3$ бала. Однак статистично значущу різницю виявили лише за доменом «фрізичне здоров'я» $(p<0,05)$ між групами 1 та 2.

Показники якості життя опікунів постінсультних пацієнтів з афразією залежно від ступеня споріднення з пацієнтом представлено в таблиці 1.

Дискусія. Відомо, що члени родини, відповідальні за надання допомоги пацієнтам, які перенесли інсульт, страждають від несприятливих наслідків захворювання [5, 7]. Однак вплив порушень мови у постінсультних пацієнтів на якість життя їхніх неофіційних опікунів вивчений недостатньо. У цьому дослідженні проведено оцінювання та аналіз якості життя родичів пацієнтів із сенсомоторною афразією в гострому періоді захворювання (1-3 тиж. після інсульту). В дослідженні взяли участь 62 опікуни, які представили різні демографічні групи: 30 жінок та 32 чоловіки від 35 до 80 років, які мали різні ступені споріднення 3 пацієнтами: діти (34 особи), подружжя (20 осіб), сиблінги (8 осіб).

Отримані результати свідчать про те, що у більшості опікунів постінсультних пацієнтів із сенсомоторною афразією погіршується фрізичне та психічне здоров'я, що узгоджується з даними попередніх досліджень [5, 7, 9].

ТАБЛИЦЯ 1 - Якість життя опікунів постінсультних пацієнтів з афазією залежно від ступеня споріднення $з$ пацієнтом

\begin{tabular}{|c|c|c|c|c|c|}
\hline \multirow{3}{*}{\multicolumn{2}{|c|}{ Показник }} & \multicolumn{4}{|c|}{ Значення показника } \\
\hline & & \multicolumn{4}{|c|}{ Домени якості життя } \\
\hline & & фізичне здоров'я & психічне здоров'я & соціальні відносини & оточуюче середовище \\
\hline \multicolumn{2}{|c|}{ Якість життя опікунів, балів } & $\bar{x} \pm S$ & $\bar{x} \pm S$ & $\bar{x} \pm S$ & $\bar{x} \pm S$ \\
\hline \multirow{3}{*}{$\begin{array}{l}\text { Групи опікунів } \\
\text { за ступенем } \\
\text { споріднення з } \\
\text { пацієнтами }\end{array}$} & Група $1(n=34)$ & $45,1 \pm 10,1$ & $50,9 \pm 10,2$ & $94,9 \pm 8,8$ & $57,3 \pm 10,5$ \\
\hline & Група $2(n=20)$ & $40,3 \pm 7,1^{*}$ & $48,7 \pm 8,6$ & $92,9 \pm 8,8$ & $54,4 \pm 12,3$ \\
\hline & Група $3(\mathrm{n}=8)$ & $42,3 \pm 10,1$ & $53,3 \pm 8,7$ & $93,9 \pm 6,3$ & $62,7 \pm 9,6$ \\
\hline
\end{tabular}

*різниця статистично значуща між показниками груп 1 та 2 при $p<0,05$ 
Суттєве зниження показника якості життя за доменом «оточуюче середовище» було пов'язане, зокрема, з фрінансовою складовою, яка входить до цього домена. Таким чином, результати дослідження підтверджують дані T. Bakas et al. [5] про те, що родичі таких пацієнтів мають фрінансові складнощі.

Водночас за доменом «соціальні відносини» зниження якості життя в опікунів постінсультних пацієнтів із сенсомоторною афазією у даному дослідженні практично не спостерігали. Такі результати можуть бути обумовлені проведенням опитування в гострому періоді захворювання. Цей період відповідає періоду стаціонарного лікування, внаслідок чого більшість проблем, пов'язаних із соціальним життям пацієнтів та опікунів, ще не набувають своєї актуальності.

Згідно $з$ отриманими результатами, зниження якості життя неофіційних опікунів пацієнтів із сенсомоторною афазією внаслідок інсульту не залежало від статі опікунів та майже не залежало від ступеня споріднення з пацієнтом. Водночас

\section{Література}

1. Закон України. Основи законодавства України про охорону здоров'я (2802 XII) [Fundamentals of the Ukrainian Legislation on Health Care (2802-ХІІ)] [Електронний ресурс]. Відомості Верховної Ради України (ВВР). 1993; 4:19. Режим доступу: https://zakon.rada.gov.ua/laws/show/2801-12\#

2. Зінченко ОМ, Міщенко ТС. Стан неврологічної служби в Україні в 2015 році [The state of the neurological service in Ukraine in 2015]. Харків, 2016. 23 c.

3. Мицкан Б, Єдинак Г, Остапяк 3, Грицуляк Б, Мицкан Т. Інсульт: різновиди, фактори ризику, фізична реабілітація [Текст] [Stroke: types, risk factors, physical rehabilitation]. Фізичне виховання, спорт і культура здоров'я у сучасному суспільстві. 2012; 3(19): 295-302.

4. Міністерство охорони здоров'я України. [Електронний ресурс] [Ministry of Health of Ukraine (2019) [Electronic resource]. 2019. Режим доступу: https://moz.gov.ua/article/news/u-2020-roci-likuvannja-gostrogomozkovogo-insultu-e-prioritetom-v-programi-medichnih-garantij

5. Bakas T, Kroenke K, Plue LD, Perkins SM, Williams LS. Outcomes among family caregivers of aphasic versus nonaphasic stroke survivors. Rehabilitation Nursing. 2006; 31(1):33-42. doi: 10.1002/j.2048-7940.2006. tb00008.x. PMID: 16422043

6. Chumney D, Nollinger K, Shesko K, Skop K, Spencer M, Newton RA. Ability of Functional Independence Measure to accurately predict functional outcome of stroke-specific population: systematic review. Journal of Rehabilitation Research \& Development. 2010; 47(1):17-29. doi: 10.1682/ jrrd.2009.08.0140. PMID: 20437324.

7. Draper BM, Poulos CJ, Cole AM, Poulos RG, Ehrlich F. A comparison of caregivers for elderly stroke and dementia victims. Journal of the American Geriatrics Society. 1992; 40(9): 896-901.

8. Elsner B, Kugler J, Pohl M, Mehrholz J. Transcranial direct current stimulation (tDCS) for improving aphasia in adults with aphasia after stroke. спостерігали тенденцію до більш тяжких наслідків захворювання для членів подружжя порівняно 3 дітьми та сиблінгами пацієнтів. Однак отримані результати не $€$ достатніми для впевнених висновків у зв'язку з обмеженнями даного дослідження, а саме: невеликими вибірками його учасників.

Висновки. Сенсомоторна афразія, яка повністю порушує здатність обробляти мовленнєву інформацію, що надходить ззовні, та відтворювати мовлення, є значним обтяжуючим фрактором після перенесеного інсульту. Вона негативним чином впливає на різні аспекти якості життя родичів тематичних хворих, які доглядають за пацієнтами. Оцінювання якості життя опікунів постінсультних пацієнтів із сенсомоторною афазією показало, що в гострому періоді захворювання спостерігається найбільше навантаження на психічне та фрізичне здоров'я опікунів.

Перспективи подальших досліджень полягають у продовженні аналізу якості життя опікунів постінсультних пацієнтів із сенсомоторною афразією в процесі лікування та реабілітації.

Cochrane Database of Systematic Reviews.2019;21;5(5):CD009760. doi: 10.1002/14651858.CD009760.pub4. PMID: 31111960; PMCID: PMC6528187.

9. Gunawan PY, Iswara KA. Correlation Between Aphasia in Stroke Patients and Severe Depression of Family Members as Primary Caregivers. Medicinus. 2021; 8(3): 94-101.

10. Hatano $S$. Experience from a multicentre stroke register: a preliminary report. Bulletin of the World Health Organization. 1976; 54(5):541.

11. Rayegani SM, Raeissadat SA, Alikhani E, Bayat M, Bahrami MH Karimzadeh A. Evaluation of complete functional status of patients with stroke by Functional Independence Measure scale on admission, discharge, and six months poststroke. Iranian journal of neurology. 2016; 15(4): 202.

12. Ross S, Morris RG. Psychological adjustment of the spouses of aphasic stroke patients. International Journal of Rehabilitation Research. 1988; 11(4): 383-6.

13. Servaes P, Draper B, Conroy P, Bowring G. Informal carers of aphasic stroke patients: Stresses and interventions. Aphasiology. 1999; 13(12): 889900.

14. World Health Organization. WHOQOL-BREF: introduction, administration, scoring and generic version of the assessment: field tria version, December 1996 (No. WHOQOL-BREF). World Health Organization, 1996. Available at: https://www.who.int/mental_health/media/en/76.pdf.

15. World Health Organization. Cardiovascular diseases fact sheet, 2007 Available at: www.who.int/mediacentre/factsheets/fs317/en/

16. World Health Organization. World health statistics 2018: monitoring health for the SDGs, sustainable development goals. World Health Organization, 2018. Available at: https://apps.who.int/iris/handle/10665/272596.

17. World Medical Association. World Medical Association Declaration of Helsinki: ethical principles for medical research involving human subjects. JAMA, 2013; 310(20), 2191-4. doi: 10.1001/jama.2013.281053 